Jurnal Bisnis dan Manajemen, Volume 22, No. 1, March 2021, p. 30-39

\title{
TESTING OF THE BLACK SCHOLES AND GARCH MODELS IN LQ45 USING LONG STRADDLE STRATEGY IN 2009-2018
}

\author{
Riko Hendrawan ${ }^{1}$, Anggadi Sasmito ${ }^{2}$ \\ ${ }^{1,2}$ Telkom University, Indonesia
}

\begin{abstract}
The purpose of this study is to examine the implementation of option contracts using Black Scholes and GARCH on the LQ45 index using the long straddle strategy. This study uses time-series data as a time frame for conducting research, using a sample of closing price data for the LQ 45 daily index for 2009-2018. For the test the model, we used the secondary data of the closing stock price index from February 28, 2009 to March 31, 2019The results of this study are seen by comparing the average percentage value of Average Mean Squared Error (AMSE) of Black Scholes and GARCH with the application of a long straddle strategy, where the smaller the percentage value, the better the model will be. Within one month of option contract due date, Black Scholes is better than GARCH, with an error value on the call option of $2.77 \%$ and the put option of $1.56 \%$. Within two months of option contract due date, GARCH is better than Black Scholes, with an error value on the call option of $8.12 \%$ and the put option of $4.00 \%$. Within three months of option contract due date, Black Scholes is better than GARCH, with an error value on the call option of $12.38 \%$ and on the put option of $5.50 \%$. The long straddle strategy in the LQ45 index only reached a maximum of $60 \%$ of possible profits, with an average of around $30 \%$ possible profits.
\end{abstract}

Keywords: Black Scholes, GARCH, Option Contract, Long Straddle

\section{PENGUJIAN MODEL BLACK SCHOLES DAN GARCH PADA INDEKS LQ45 MENGGUNAKAN STRATEGI JANGKA PANJANG TAHUN 2009-2018}

\begin{abstract}
ABSTRAK
Tujuan dari penelitian ini adalah untuk menguji penerapan kontrak opsi menggunakan model opsi Black Scholes dan model opsi GARCH pada index LQ45 dengan menggunakan strategi long straddle. Menggunakan data harga penutupan indek LQ45 dari 2009 hingga tahun 2019 untuk periode observasi dan untuk periode pengujian menggunakan data dari Bulan Februari 2009 hingga maret 2019. Hasil dari penelitian ini dilihat dengan membandingkan nilai persentase rata-rata akar kuadrat kesalahan dari Model Black Scholes dan GARCH dengan penerapan strategi long straddle, dimana semakin kecil nilai persentasenya, maka model akan semakin baik. Dari hasil penelitian menunjukkan bahwa untuk 1 bulan jatuh tempo kontrak opsi, model Black Scholes lebih baik dari pada GARCH dengan nilai kesalahan pada opsi call sebesar 2.77\%, dan pada opsi put sebesar 1.56\%. Dalam 2 bulan jatuh tempo kontra kopsi, model GARCH lebih baik dari pada Black Scholes dengan nilai kesalahan pada opsi call sebesar $8.12 \%$, dan pada opsi put sebesar 4.00\%. Dalam 3 bulan jatuh tempo kontrak opsi, model Black Scholes lebih baik dari pada GARCH dengan nilai kesalahan pada opsi call sebesar $12.38 \%$, dan pada opsi put sebesar $5.50 \%$. Penggunaan strategi long straddle pada index LQ45 pada tahun 2009-2018 hanya mencapai maksimal 60\% kemungkinan keuntungan, dengan rata-rata kemungkinan keuntungan sekitar $30 \%$.
\end{abstract}

Kata-kata Kunci: Black-Scholes, GRACH, Kontrak Opsi, Long Straddle

${ }^{1}$ Korespondensi : Riko Hendrawan. Program Magister Manajemen Universitas Telkom, Jln. Geger Kalong Hilir No. 47 Bandung, Jawa Barat, Indonesia. Email : riko_hendrawan@yahoo.com. 
Jurnal Bisnis dan Manajemen, Volume 22, No. 1, March 2021, p. 30-39

\section{INTRODUCTION}

Investment is the activity of placing funds in a place with the hope to get profits in the future in a certain period. One alternative for investing in financial assets is in the capital market (which connects investors with companies or government institutions through trading financial instruments, such as stocks, bonds, currencies). The magnitude of the risk in an investment in the capital market can be seen from the tendency to change the closing price of an index/stock that is very significant. Based on Figure 1 below, it can be seen that the daily yields on the LQ45 index on the Indonesia Stock Exchange (IDX) tend to be very volatile and have very significant changes.

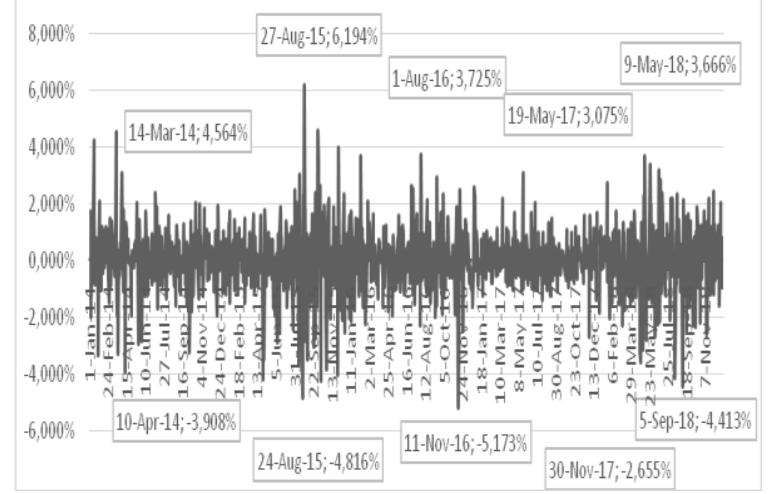

Figure 1. Graph of LQ 45 Returns for the 2009-2018 Period

The graph in Figure 1 above shows the movement of LQ45 index yields for the 20142018 period. In plain view, in the last five years the maximum rate of return on August 27, 2015, was $6,194 \%$ and the lowest rate of return on November 11, 2016, was -5,173\%.
Table 1. LQ45 Highest and Lowest Returns in the last 19 years

\begin{tabular}{|c|c|c|c|c|}
\hline \multicolumn{2}{|c|}{ Lowest Daily Returns } & \multicolumn{2}{|c|}{ Highest Daily Returns } & \multirow{2}{*}{$\begin{array}{c}\text { Range } \\
\%\end{array}$} \\
\hline Date & Percentage & Date & Percentage & \\
\hline 26-Apr-18 & $-3.59 \%$ & 9-May-18 & $4.83 \%$ & $8.42 \%$ \\
\hline 30-Nov-17 & $-2.45 \%$ & 19-May-17 & $3.13 \%$ & $5.58 \%$ \\
\hline 11-Nov-16 & $-3.34 \%$ & 5 -Feb-16 & $3.44 \%$ & $6.78 \%$ \\
\hline 13-Oct-15 & $-3.96 \%$ & 29-Sep-15 & $4.37 \%$ & $8.34 \%$ \\
\hline 30-May-14 & $-3.17 \%$ & 14-Mar-14 & $5.68 \%$ & $8.85 \%$ \\
\hline 19-Aug-13 & $-5.60 \%$ & 28-Aug-13 & $4.68 \%$ & $10.28 \%$ \\
\hline 4-Apr-12 & $-2.62 \%$ & 6-Jun-12 & $3.11 \%$ & $5.73 \%$ \\
\hline 22-Sep-11 & $-10.08 \%$ & 27-Sep-11 & $5.30 \%$ & $15.37 \%$ \\
\hline 5-May-10 & $-4.16 \%$ & 26-May-10 & $7.91 \%$ & $12.07 \%$ \\
\hline 18-Jun-09 & $-4.12 \%$ & 13-Apr-09 & $5.97 \%$ & $10.09 \%$ \\
\hline $8-O c t-08$ & $-8.13 \%$ & 16-Sep-08 & $9.75 \%$ & $17.88 \%$ \\
\hline 15-Aug-07 & $-4.52 \%$ & 28-Feb-07 & $5.13 \%$ & $9.65 \%$ \\
\hline 22-May-06 & $-6.64 \%$ & 23-May-06 & $4.32 \%$ & $10.96 \%$ \\
\hline 29-Aug-05 & $-3.99 \%$ & 30-Aug-05 & $7.47 \%$ & $11.46 \%$ \\
\hline 17-May-04 & $-8.24 \%$ & 20-Apr-04 & $3.89 \%$ & $12.13 \%$ \\
\hline 2-Jan-03 & $-4.00 \%$ & 7-Apr-03 & $5.34 \%$ & $9.34 \%$ \\
\hline 14-Oct-02 & $-11.07 \%$ & 6-Mar-02 & $4.83 \%$ & $15.90 \%$ \\
\hline 17-Sep-01 & $-4.43 \%$ & 2-Feb-01 & $6.26 \%$ & $10.69 \%$ \\
\hline 11-Dec-00 & $-3.20 \%$ & 6-Nov-00 & $2.67 \%$ & $5.87 \%$ \\
\hline Average & $-5.12 \%$ & Rata-Rata & $5.16 \%$ & $10.28 \%$ \\
\hline
\end{tabular}

If investigated in the past 19 years (Table 1), it appears that the fluctuations in the value of the yields that occur are higher. On October 14, 2002 , the value of the yield reached its lowest point in 19 years, which is $-11.07 \%$. The highest yield occurred on September 16, 2008, which was $9.75 \%$. The highest volatility fluctuation range occurred in 2008 , reaching $17.88 \%$. The annual average for the lowest and highest yields is $5.12 \%$, and $5.16 \%$, with an average annual fluctuation range of $10.28 \%$.

The data shown in table 1 shows that high volatility occurring on the LQ45 index poses a risk for investors. What if there is an instrument that can protect an investment (as a hedging 
Jurnal Bisnis dan Manajemen, Volume 22, No. 1, March 2021, p. 30-39

function). In the investment world, there is a derivative instrument called an option contract that provides investment options, where when investment projections move up, investors can buy call options, and vice versa when investment projections move down, investors can buy put options. The maximum loss from an option contract investment is as much as the premium and the benefits are unlimited (limited risk, unlimited return).

There was an explosive growth in the derivative trading activities of financial markets around the world when Black Scholes (1973) discovered the Black Scholes Model to determine the price of put and call options. However, there are limitations, where the volatility, which is one of the parameters in the Black Scholes equation, is assumed to be constant. As a matter of fact, volatility not only changes over time but also with different due dates and execution prices for an underlying asset will create a difference in volatility smile. This makes the problem more complex and requires the right approach.

Several studies that have conducted similar studies include, Hendrawan (2010), Rajvanshi (2017), Mathoera (2016), Ekstrom (2015), Kaminski (2013), Gabriel (2012), and Su (2010). Some previous studies in the world have compared the price of options with different volatility approaches to determine which model is the best, but not many have tested the market in Indonesia. As the LQ45 index grows, and the absence of implementation of option contracts in the Indonesian market makes the option market more viable for deeper study.

This research is focused on testing and comparing several models with different volatility approaches on the LQ45 index to determine which model is more accurate. The application of the strategy in investing in an option contract is what will determine the size of the investment. The choice of strategy will be influenced by the volatility of an investment object. The option strategy used in this study is the long straddle strategy, a strategy that is believed to be able to cope with very volatile market conditions, and investors are not sure whether price movements will rise or fall as they mature. In this strategy, the investor buys put options and call options simultaneously with the same execution and due date prices. Based on the data \& phenomena above, this study aims to test the implementation of option theory on the LQ45 index for a period of 1, 2, and 3 months with the Black-Scholes and GARCH methods using the long straddle strategy in 2009-2018.

\section{LITERATURE REVIEW}

\section{Option Contract}

An option contract is an agreement/contract between an option seller (seller or writer) and an option buyer (buyer), where the option seller guarantees the right (not an obligation) of the option buyer to buy or sell certain issuers at a specified time and price (Hull, 2009). 
Jurnal Bisnis dan Manajemen, Volume 22, No. 1, March 2021, p. 30-39

Based on the rights that occur, the options are grouped into two, namely, call options and put options. For the call option, investors who buy call options will expect the price of an issuer will rise and take advantage of the price increase. In the put option, investors who buy put options will expect the price of an issuer at the due date to be below the agreed price.

\section{Black Scholes Option Model}

In early 1973 Fisher Black, Myron Scholes, and Robert Merton discovered a breakthrough in the formation of an option price. Then this breakthrough became known as the Black-Scholes model. Black Scholes contribute fundamentally to the formation of option prices. Black Scholes makes the risk-free asset variable (risk-free asset) to be the basis in calculating the expected return (expected rate of return), this variable will replace the expected return variable.

The Black \& Scholes formula equation for call options is as follows

$C=S N(d 1)-e^{-}$

${ }^{R f T} X N(d 2)$

Whereas the equation for the put option is as follows:

$P=X e^{-R f T} N(-d 2)-S N(-$

d1).

Where:

1 .

$d 2=d 1-\sigma \sqrt{T}$

With:

$\mathrm{S} \quad=$ spot price of a stock

$\mathrm{X}=$ execution price

TESTING OF THE BLACK SCHOLES AND GARCH MODELS IN LQ45 USING LONG STRADDLE STRATEGY IN 2009-2018

(Riko Hendrawan, Anggadi Sasmito)
$\mathrm{T}=$ expiration date / Option contract due date

$\mathrm{Rf}=$ risk free interest rate / SBI

$\Sigma=$ volatility of stock prices

$\mathrm{C}=$ value of call options per share

$\mathrm{P}=$ value of put options per share

$\mathrm{N}\{\}=$. Probability cumulative distribution for a normally distributed variable with mean $=0$ and standard deviation 1

From various developments regarding research on volatility modeling, there is the GARCH (1.1) model proposed by Bollerslev (1986). Where the GARCH equation $(1,1)$ is

$$
\sigma_{n}^{2}=\gamma V_{L}+\alpha u_{n-1}^{2}+.
$$

If the weight $\gamma$ represents $V_{L}$, the weight $\alpha$ represents $u^{2}(n-1)$, and the weight $\beta$ represents $\sigma_{(n-}^{2}$ 1), then the whole constant if added must be $=1$.

$$
+=1 \text {. }
$$

If determined that $\omega=\gamma V_{L}$, then the GARCH (1.1) model can be written as:

$$
\sigma^{2}=\omega+\alpha u_{n-1}^{2}+.
$$

Duan's research (1995) states that the GARCH volatility modeling framework can be used to make model GARCH options. The research was then continued by Heston Nandi (2000), where Nandi used the Black Scholes option model to find the value of the option at the due date.

The GARCH volatility determination process is formed by determining the best lag of ARIMA, by going through the stationary test process, ADF test (Augmented Dickey-Fuller) and

\section{GARCH Option Model}


Jurnal Bisnis dan Manajemen, Volume 22, No. 1, March 2021, p. 30-39

searching for models from Akaike (AIC), Schwartz Criterion (SIC), Adjusted R2, Sum Squared Residual (SSR) best on each model.

\section{Long Straddle Strategy}

A straddle is appropriate when an investor is expecting a large move in a stock price but does not know in which direction the move will be (Hull, 2009). It will provide benefits if adequate stock price movements, both for rising and falling prices. Figure 2 illustrates the payoff diagram of long straddle strategy. In this strategy, investors will buy put options and call options with the same benchmark, due date and execution price. This strategy provides unlimited profit potential for very high volatility conditions.

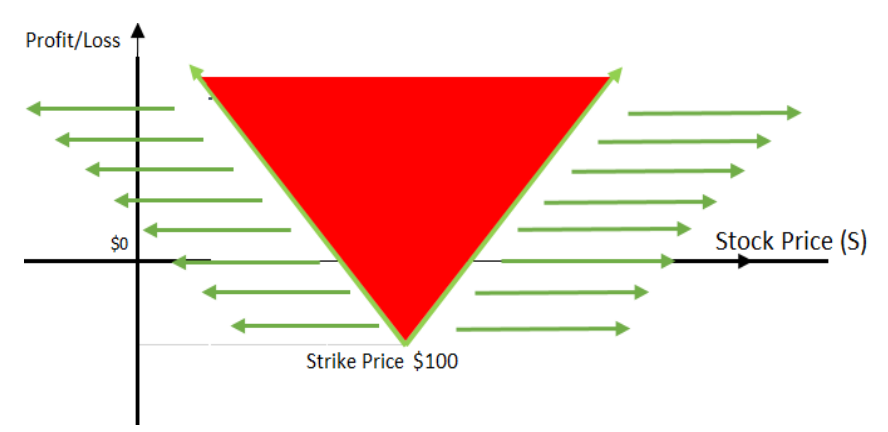

\section{Figure 2. Payoff Diagram of a long straddle strategy}

\section{Previous Research}

Hendrawan (2018) identified the occurrence of shock volatility and its implications for the yield of an investment using IHSG data from 19982016 and applying the long straddle option strategy by dividing the range of data into 2 phases, namely high volatility and low volatility. At the end of his study, Hendrawan stated that in the IDX market, the potential profit (for put \& call option holders) or potential losses (for put and call option sellers) due to volatility was $40.51 \%$. With the implementation of the long straddle strategy, profit potential (for put \& call option holders) increased in 1998 to $58.24 \%$ and $76.47 \%$ in 2008 .

Rajvanshi (2017) compared the performance of several GARCH models (GARCH， GJR-GARCH \& EGARCH) and implied volatility. Rajvansi compared the performance of the models using Mean Absolute Error (MAE) and Root Mean Squared Error (RMSE). At the end of the study, Rajvansi concluded that the GARCH model with implied volatility was the best model among GJRGARCH \& EGARCH.

Mathoera (2016) conduct research on the AEX and SP500, Ekstrom (2015) on the WIG20 index, that under ATM (At The Money) conditions, using RMSE calculation, Black Scholes option contract value with historical volatility is better compared to GARCH in both call and put options

Kaminski (2013) conducted a study of the modeling of Option prices on the WIG20 index. Syzmon compares three well-known models, namely Black Scholes, GARCH and the Duan (1995) approach. In his research, Syzmon concluded that the Black Scholes Model with the GARCH volatility approach is the best among the other models; this can be seen from the value of Mean Absolute Pricing Errors (MAPE) \& Median Absolute Pricing Errors (MdAPE), which is the smallest. 
Jurnal Bisnis dan Manajemen, Volume 22, No. 1, March 2021, p. 30-39

Gabriel (2012) evaluates the performance of volatility modeling using the GARCH model on the BET Index (Romania). Gabriel made a comparison between the GARCH, EGARCH, TGARCH, PGARCH, IGARCH models. The accuracy of the modeling is calculated using Root Mean Square Error (RMSE), the Mean Absolute Error (MAE), Mean Absolute Percentage Error (MAPE), and Theil Inequality Coefficient (TIC). From the calculations, it was found that TGARCH \& GARCH has the best performance among other models.

\section{METHODS}

This research uses quantitative methods with comparative and descriptive approaches, namely research conducted with the aim that researchers know the comparison between testing the Black Scholes and GARCH models on the LQ45 index. This study uses time-series data as a time frame for conducting research, using a sample of closing price data for the LQ 45 daily index for the period 2009-2018. For the test of the model, we used the secondary data of the closing stock price index for the period of February 28, 2009, to March 31, 2019. If the due date falls on a holiday, then the execution date uses the price of the working day after the holiday (Hendrawan, 2017).

Error Rate calculation is done by the AMSE (Average Mean Squared Error) method, the analytical method used to test a model where the smaller the value, the better the model.

$$
\mathrm{AMSE}=\quad \frac{1}{N} \sum_{t=1}^{N} \mathrm{O}^{2 \ldots}
$$

With,

Apt $=$ Value of Actual Option Premium

SPt $=$ Value of Premium Option calculation results

$\mathrm{N}=$ Number of Experiments performed.

\section{RESULTS}

\section{Comparison of Volatility}

Volatility calculations are performed using historical volatility (with one month, two months and three months historical data) and GARCH within 10 years observation data obtained with the following results on table 2 below :

Table 2. Comparison of volatility calculations

\begin{tabular}{|l|c|c|c|}
\cline { 2 - 4 } \multicolumn{1}{c|}{} & Average & Max & Min \\
\hline $\begin{array}{l}\text { Historical Volatility } \\
\text { (1 month) }\end{array}$ & $1.243 \%$ & $3.79 \%$ & $0.38 \%$ \\
\hline $\begin{array}{l}\text { Historical Volatility } \\
(2 \text { month) }\end{array}$ & $1.259 \%$ & $3.01 \%$ & $0.47 \%$ \\
\hline $\begin{array}{l}\text { Historical Volatility } \\
\text { (3 month) }\end{array}$ & $1.263 \%$ & $2.75 \%$ & $0.49 \%$ \\
\hline GARCH & $1.287 \%$ & $3.52 \%$ & $0.67 \%$ \\
\hline
\end{tabular}

From Table 2, it can be seen that the greater the number of observations made on historical volatility, the average value of volatility will be higher. Changes in volatility are also seen linearly at maximum volatility in historical volatility; the more number of observations made, the maximum value of volatility will be lower. Alternately at minimum volatility, the more number of observations made, the minimum value of volatility will be higher. The GARCH model has the highest average volatility, which is 
Jurnal Bisnis dan Manajemen, Volume 22, No. 1, March 2021, p. 30-39

$1,287 \%$. The maximum volatility is found in the GARCH model. The volatility value is seen to be between historical volatility, which is $3.52 \%$, but the minimum volatility value in GARCH is higher among other volatility models, which is $0.67 \%$. From the 3-month historical volatility data, the average value is getting bigger, the maximum value is getting smaller, and the minimum is getting bigger. This can be concluded that the greater the historical period in historical volatility, the volatility value will go to a point (the range of volatility in historical volatility decreases).

\section{Testing Black Scholes and GARCH Models}

The testing of Black Scholes and GARCH models can be seen in Table 3. At the due date of 1 month, the Black Scholes Model is better than the GARCH Model with an average percentage of square root error in call options of $2.77 \%$ and put options at $1.56 \%$. Whereas in the GARCH Model, the average value of the square root error in the call option is $3.25 \%$ and in the put option is $1.89 \%$.

\section{Table 3. Comparison of AMSE Black Scholes} vs. GARCH values

\begin{tabular}{clcc}
\hline & \multirow{2}{*}{ MODEL } & \multicolumn{2}{c}{ AMSE } \\
& & CALL & PUT \\
\hline 1 & Black Scholes 1 Month & $\mathbf{2 . 7 7 \%}$ & $\mathbf{1 . 5 6 \%}$ \\
Month & GARCH(1,1) 1 Month & $3.25 \%$ & $1.89 \%$ \\
2 & Black Scholes 2 Month & $8.12 \%$ & $4.00 \%$ \\
Month & GARCH(1,1) 2 Month & $\mathbf{7 . 1 7 \%}$ & $\mathbf{3 . 3 4 \%}$ \\
3 & Black Scholes 3 Month & $\mathbf{1 1 . 4 2 \%}$ & $\mathbf{4 . 8 6 \%}$ \\
Month & GARCH(1,1) 3 Month & $13.08 \%$ & $5.96 \%$ \\
\hline
\end{tabular}

Source: processed data
In testing between the Black Scholes and GARCH models at 2 months due date, the GARCH Model is better than the Black Scholes, as seen from the average value of the square root error in the call option of $7.17 \%$ and the put option of $3.34 \%$. Whereas in the Black Scholes Model, the average value of the square root error in the call option is $8.12 \%$ and in the put option is $4 \%$.

In testing between the Black Scholes and GARCH models at three months due date, the Black Scholes Model is better than GARCH, it can be seen from the average value of the square root error in the call option of $11.42 \%$ and the put option of $4.86 \%$. Whereas in the Black Scholes Model, the average value of the square root error in the call option is $13.08 \%$ and in the put option is $5.96 \%$.

The testing of the long straddle strategy can be seen in Table 4. The average percentage with the 2009-2018 testing period in the profit area looks smaller than the loss area. The table below shows that the average percentage of testing is only around $30 \%$, a maximum average of $39.83 \%$. 
Jurnal Bisnis dan Manajemen, Volume 22, No. 1, March 2021, p. 30-39

Table 4. Comparison of profit and loss possibilities with long straddle strategy

\begin{tabular}{clccc}
\hline $\begin{array}{c}\text { Due } \\
\text { date }\end{array}$ & MODEL & $\begin{array}{c}\text { Profit } \\
\text { area }\end{array}$ & Loss area & Percentage \\
\hline 1 & Black Scholes 1 Month & 863 & 1555 & $35.69 \%$ \\
Month & GARCH(1,1) 1 Month & 792 & 1646 & $32.49 \%$ \\
2 & Black Scholes 2 Month & 499 & 1899 & $20.81 \%$ \\
Month & GARCH(1,1) 2 Month & 463 & 1975 & $18.99 \%$ \\
3 & Black Scholes 3 Month & 953 & 1445 & $39.23 \%$ \\
Month & GARCH(1,1) 3 Month & 971 & 1467 & $39.83 \%$ \\
\hline
\end{tabular}

Source: data processed

From 10 years of observation of the Black Scholes and GARCH models using the long straddle strategy (in Table 5), it appears that the maximum likelihood of profit occurred in 2009 with a due date of 3 months, amounting to $60.17 \%$ and the lowest possible profit was in 2013 with a due date of 2 months, which is $9.80 \%$ per year.

Table 5. Percentage of possible profits with a long straddle strategy in each test year

\begin{tabular}{|c|c|c|c|c|c|c|}
\hline \multirow[b]{2}{*}{ Year } & \multicolumn{2}{|c|}{1 Month } & \multicolumn{2}{|c|}{2 Month } & \multicolumn{2}{|c|}{3 Month } \\
\hline & $\begin{array}{c}\text { Black } \\
\text { Scholes }\end{array}$ & GARCH & $\begin{array}{c}\text { Black } \\
\text { Scholes }\end{array}$ & GARCH & $\begin{array}{c}\text { Black } \\
\text { Scholes }\end{array}$ & GARCH \\
\hline 2009 & $46.06 \%$ & $48.13 \%$ & $27.39 \%$ & $30.29 \%$ & $45.23 \%$ & $60.17 \%$ \\
\hline 2010 & $41.39 \%$ & $41.39 \%$ & $28.69 \%$ & $25.82 \%$ & $47.54 \%$ & $45.90 \%$ \\
\hline 2011 & $38.62 \%$ & $36.59 \%$ & $21.95 \%$ & $19.92 \%$ & $25.20 \%$ & $28.86 \%$ \\
\hline 2012 & $29.39 \%$ & $23.67 \%$ & $13.06 \%$ & $8.98 \%$ & $27.35 \%$ & $24.49 \%$ \\
\hline 2013 & $45.68 \%$ & $43.21 \%$ & $27.57 \%$ & $28.40 \%$ & $45.27 \%$ & $44.03 \%$ \\
\hline 2014 & $25.49 \%$ & $21.57 \%$ & $9.80 \%$ & $10.59 \%$ & $35.69 \%$ & $33.33 \%$ \\
\hline 2015 & $34.16 \%$ & $33.33 \%$ & $23.05 \%$ & $19.34 \%$ & $44.03 \%$ & $44.86 \%$ \\
\hline 2016 & $33.61 \%$ & $29.51 \%$ & $16.39 \%$ & $17.62 \%$ & $30.33 \%$ & $32.38 \%$ \\
\hline 2017 & $31.93 \%$ & $23.53 \%$ & $20.17 \%$ & $13.03 \%$ & $\mathbf{5 0 . 0 0 \%}$ & $42.86 \%$ \\
\hline 2018 & $28.33 \%$ & $24.17 \%$ & $17.08 \%$ & $16.25 \%$ & $40.83 \%$ & $42.08 \%$ \\
\hline
\end{tabular}

Source: processed data

\section{DISCUSSION}

This research theoretically proves that the long straddle strategy seems not the best strategy for the implementation of options contract in LQ45 index on 2009 - 2018. The average profit using the long straddle strategy is only around $30 \%$, with the maximum profit potential occurring in 2009 with a due date of 3 months, which is $60 \%$.

Furthermore, the results of the error value obtained from 3 months' different due date, show that the error value increases linearly with the amount of due date on the contract TESTING OF THE BLACK SCHOLES AND GARCH MODELS IN LQ45 USING LONG STRADDLE STRATEGY IN 2009-2018 (Riko Hendrawan, Anggadi Sasmito) 
Jurnal Bisnis dan Manajemen, Volume 22, No. 1, March 2021, p. 30-39

option. This indicates that in option contract, the potential for a model's have a mistake in determining the fair price of an option contract will be directly proportional to the length of due date taken by the investor.

The results of the study also indicate that the Black Scholes Model is better than GARCH based on the error values obtained using the long straddle strategy. These results are similar to studies conducted by Mathoera (2016) on the AEX \& SP500, Ekstrom (2015) on the WIG20 index, that under ATM (At The Money) conditions, using RMSE calculation, Black Scholes option contract value with historical volatility is better compared to GARCH in both call and put options.

In contrast to research conducted by Kaminski (2013) which uses the WIG20 index object and Su (2010) on the FTSE 100 index which states that the GARCH model outperforms Black Scholes in modeling an option price based on a better MAPE value on put options and call options.

\section{CONCLUSION}

From the results of the study, it was concluded that the use of option contracts in the LQ45 index is generally better using the Black Scholes Model than GARCH; this is seen in the average value of the square root error in call and put options at different maturities (one month and three months due date) has a smaller error value than the GARCH model. In this study, the GARCH option model is only superior when the 2-month option due date, where the GARCH option model has a smaller error value for put and call options.

The long straddle strategy did not produce significant results in the implementation of option contracts on the LQ45 index. Based on testing with a due date of one month, two months, and three months, the maximum of an option contract has a profitability of $60.17 \%$ and minimum profitability of $9.80 \%$. The average profitability is around $31 \%$. The due date of the option contract gives a linear effect on the percentage of errors of each model. The greater the due date, the error value on the AMSE will be even greater, and vice versa; the smaller the maturity, the error value on the AMSE will be smaller. It applies to call options as well as put options.

\section{REFERENCES}

Black, F., \& Scholes, M. (1973). The Pricing of Option and Corporate Liabilities. Journal of Political Economy Vol.81, No.3, 637 654.

Bollerslev, T. (1986). Generalized Autoregressive Conditional Heteroscedasticity, Journal of Econometrics 31, 307-327.

Duan, J.-C., (1995), The GARCH Option Pricing Model, Mathematical Finance 5, 13-32.

Ekstrom(2015). Implementation of Heston-Nandi GARCH model on OMXS30, Put and call valuation, pre and post the financial crisis of 2008. City of Lund: Lund University.

Gabriel, A. S. (2012). Evaluating the Forecasting Performance of GARCH Models. Evidence from Romania. Procedia - Social and Behavioral Sciences 62 ( 2012 ) 1006 -1010 .

Hendrawan, R. (2010). Perbandingan Model Opsi Black-Scholes dan Model Opsi 
Jurnal Bisnis dan Manajemen, Volume 22, No. 1, March 2021, p. 30-39

GARCH di Bursa Efek Indonesia, Jurnal Keuangan dan Perbankan Vol.14, No.1, 2010. Penerbit : Universitas Merdeka Malang.ISSN :1410-8089 ISSN :14108089

Hendrawan, R (2017). Forward, Forward Option and No Hedging Which One is the Best for Managing Currency Risk?Jurnal Keuangan dan Perbankan . Vol. 21, No.3, 2017 Penerbit : Universitas Merdeka Malang. ISSN : 1410-8089

Hendrawan, R. (2018). Assesing Shock Volatility using Long Straddle Option Strategy: Evidence at IDX Composite. Jurnal Keuangan dan Perbankan, 1-13. ISSN :1410-8089

Heston, L Steven and Saikat Nandi, (2000). “ A Closed - Form GARCH Option Pricing Model “, Review Financial Studies, 13, $585-626$.

Hull, J. (2009). Options, Futures, and other Derivatives. Pearson Prentice Hall

Kaminski, S. (2013). The pricing of options on WIG20 using GARCH models, Working Papers ,2013-06, Faculty of Economic Sciences, University of Warsaw

Mathoera, MMS (2016). Does any model beat the GARCH (1.1)? A Forecast comparison of volatility models through option prices., Thesis Erasmus University, Rotterdam.

Rajvanshi, V. (2017). Implied Volatility and Predictability of GARCH Models. Kolkata: Indian Institute of Management Calcutta.

Su, Y. (2010). An application of closed-form GARCH option-pricing model on FTSE 100 option and volatility. Applied Financial Economics, 2010, 20, 899-910. 